\title{
Complications of Sinusitis: About 9 Cases in the Ear Nose \& Throat (ENT) Department of the University Hospital Gabriel Touré in Bamako
}

\author{
Kadidiatou Doumbia-Singare1, Abdoul Aziz Diakite2, Sidiki N'Dao1, Samba Karim Timbo1, \\ Youssouf Sogoba ${ }^{3}$, Drissa Kanikomo ${ }^{3}$, Boubacary Guindo' ${ }^{1}$, Siaka Soumaoro', \\ Lamine Traore', Fatogoma Kone', Fatou Sylla', Mohamed Keita', Alhousseini Ag Mohamed ${ }^{1}$ \\ ${ }^{1}$ ENT Department and Neck Surgery of the University Hospital Gabriel Toure, Bamako, Mali \\ ${ }^{2}$ Neurosurgery Department of the University Hospital Gabriel Toure, Bamako, Mali \\ ${ }^{3}$ Pediatric Department of the University Hospital Gabriel Toure, Bamako, Mali \\ ${ }^{4}$ African Institute of Tropical Ophthalmology, Bamako, Mali \\ Email: kadidia22000@yahoo.fr
}

Received 12 June 2015; accepted 11 January 2016; published 14 January 2016

Copyright (C) 2016 by authors and Scientific Research Publishing Inc.

This work is licensed under the Creative Commons Attribution International License (CC BY).

http://creativecommons.org/licenses/by/4.0/

(c) (i) Open Access

\begin{abstract}
Objective: This study aims to analyze clinical, paraclinical and therapeutic aspects of sinusitis complications in the Otorhinolaryngology department at the teaching hospital of Gabriel Toure in Bamako. Materials and methods: This descriptive and longitudinal study was conducted on 12 months from March 2012 to February 2013 in 9 cases of sinusitis complications in the department of Otorhinolaryngology at the University Hospital Gabriel Toure in Bamako. Results: The average age of patients was 22.7 years; a median of 19 years within 6 men and 3 women with almost 12.9 days of care seeking duration. The factors of risky were the use of nonsteroid anti-inflammatory drugs NSAID ( 4 cases), maxillofacial trauma (1 case) and HIV (1 case). Facial pain was the major symptom, such as frontal oedema, rhinorrhea with pus shedding and nasal obstruction. Computer tomography was used for complications specification. Frontal sinusitis was the most encountered with subperiosteal abscess (44.4\%). Streptococcus pneumoniae was identified in 3 cases. Medical treatment associated to surgery was conducted on 7 patients. Two cases of death have been registered. Conclusion: The complicated sinusitis is an emergency and dangerous disease requiring specific care by a multidisciplinary staff. Much of complications are commonly encountered despite the antibiotic era.
\end{abstract}

\section{Keywords}

Sinusitis, Complications, Diagnosis, Treatment, Surgery

How to cite this paper: Doumbia-Singare, K., et al. (2016) Complications of Sinusitis: About 9 Cases in the Ear Nose \& Throat (ENT) Department of the University Hospital Gabriel Touré in Bamako. Surgical Science, 7, 27-33.

http://dx.doi.org/10.4236/ss.2016.71003 


\section{Introduction}

The complications of sinusitis are defined by the extension and spread of sinusal attack to structures and adjacent tissues [1].

These complications are most of time orbital and cranial because of the anatomical situation of these structures [2] [3]. The outcomes of sinusitis complications can be central nerves injuries (hemiplegia, blindness) more or less severe after recovery [3]-[6]. However, the symptoms of these complications can be variable or dismiss antibiotic abuse [4].

Computer tomography with or without contrast has become the gold standard for complications identification [1] [5] [7] [8].

The treatment of sinusitis complications requires a multidiscipline staff and close monitoring system [4].

The aim of this study was to analyze the clinical, paraclinical and therapeutic aspects of sinusitis complications.

\section{Materials and Methods}

It was a prospective descriptive and longitudinal study having as framework the ENT department of CHU Gabriel Touré in Bamako, Mali from March 2012 to February 2013.

The proposal of this topic have been presented and approved by the Research Ethic Committee of Mali. Fervor information and opinion of the patient were obtained the survey.

\section{Results}

The series consisted of 9 patients of those 6 were male and 3 female. The average age was 22.7 years with a median of 19 years, extreme were 6 and 51 years.

The time from first symptoms to care seeking ranged from 1 to 21 days with an average of 12.9 days. As auto medication 4 patients used non-steroidal anti-inflammatory drugs, 3 cases of none specify antibiotics and one case of maxillofacial trauma from traffic accident. The major symptoms were fever, unilateral nasal obstruction and purulent rhinorrhea. Headache was found in 3 patients and proptosis in one patient. Five patients had neurological signs. A frontal swelling was found in 4 patients.

The main complications were: subperiosteal abscess of the frontal (4 cases) (Figure 1), subperiosteal abscess of the orbit (1 case), thrombophlebitis of the cavernous sinus (1 case), the endocranial complications (3 cases including 2 cases of subdural empyema with subperiosteal abscess; one case of frontal or brain abscess).

The sinuses involved in the complications were: isolated frontal sinus in 4 cases, the isolated ethmoid sinus in 2 cases, the pansinusitis (sinusitis ethmoido fronto-maxillary) in 3 cases.

The computer tomography was used to perform the diagnosis (Figure 2, Figure 3).

Hyperleucocytosis more than 12,000/ml has been found in all patients associated with high rate C-reactive protein more than $50 \mathrm{ml} / \mathrm{L}$. HIV serology was positive in one patient.

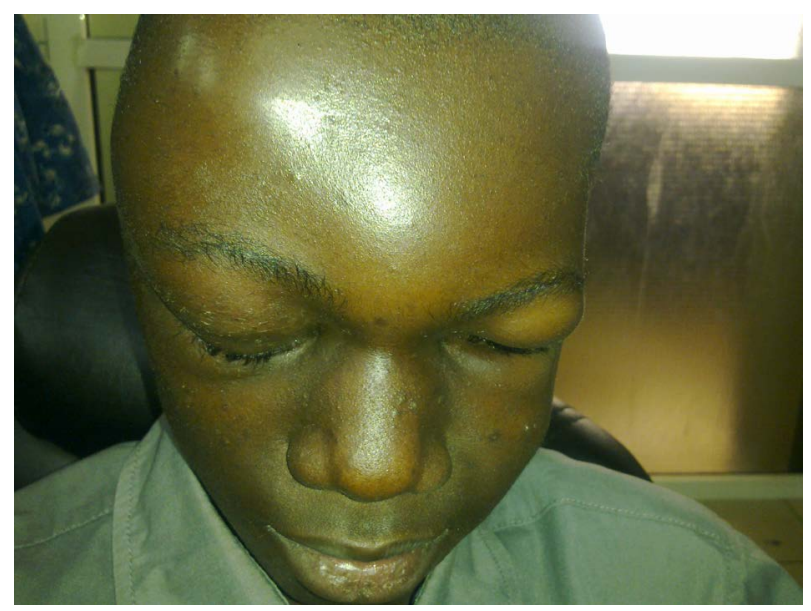

Figure 1. Patient male, 14-years old who have a subperiosteal abscess of the frontal. 


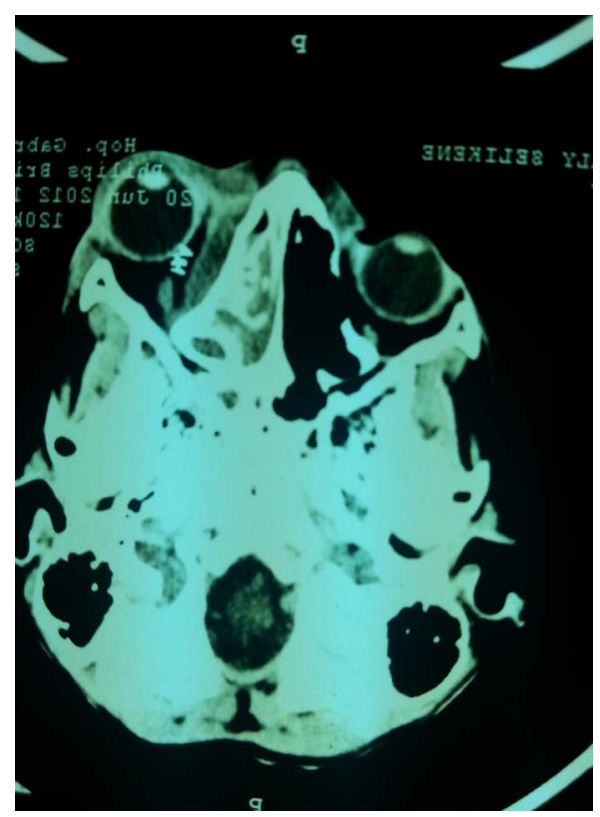

Figure 2. 6 years old male patient, CT (computed tomography) sinuses in axial section showing a subperiosteal abscess of the orbit and ethmoid sinusitis.

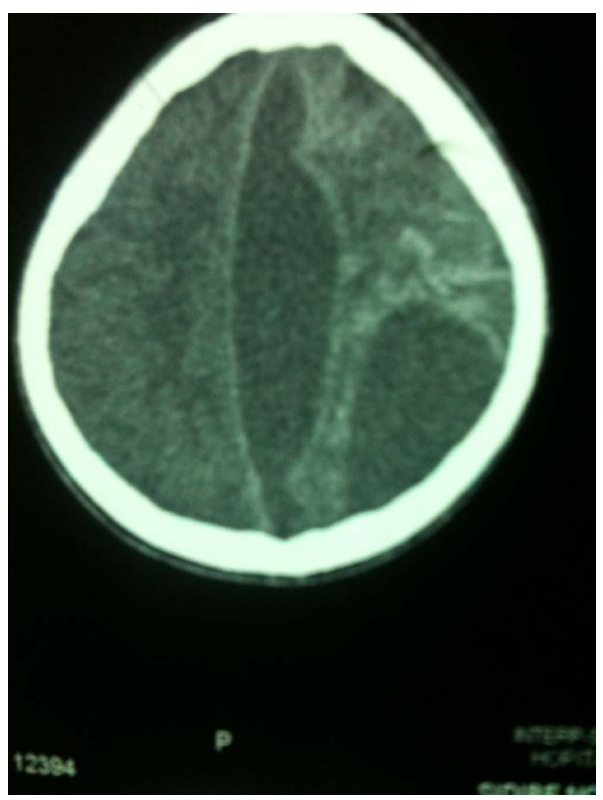

Figure 3. 16 years old female patient, brain CT showing subdural abscess.

Streptococcus pneumoniae (3 cases), Pseudomonas aeruginosa (1 case) and Staphylococcus (1 case) were identify. Amoxicillin-clavulanic acid, cefotaxime, to metronidazoles and quinolones were recommended to destroy all these pathogen agents.

Antibiotherapy has consisted to a combination of cefotaxime and metronidazole in 5 cases administered by parenteral route at the rate of $3 \mathrm{~g} /$ day and $1.5 \mathrm{~g}$ metronidazole/amoxicillin-clavulanic acid $3 \mathrm{~g} /$ day and gentamicin in 4 cases. For children under $30 \mathrm{~kg}$ ( 2 cases), the doses have been adapted to their weight. The average duration of antibiotic therapy has been 28 days range from 8 to 45 days. 
Besides medical treatment, 7 patients have benefited surgical treatment which was performed under general anesthesia by the otorhinolaryngology team in 5 cases and the neurosurgery staff in 2 cases. This treatment has consisted to an external drainage of frontal abscess and frontal sinus, an external drainage of subperiosteal orbit abscess. Dural abscesses have been drained by the neurosurgery team.

The outcomes were successful in 7 cases marked by the disappearance of the clinical signs. Two cases of death have been registered, including one case of cavernous thrombosis and one case of brain abscess. The reasons for the deaths were due to the bad clinical state since the admission (Table 1, Table 2).

\section{Discussion}

Nine cases of orbital and intracranial complications of sinusitis were collected, from March 2012 to February 2013. The series was less than those found by some authors respectively 80 cases in 6 years and 47 cases in 2 years [2] [9].

These complications usually occur in young population (20 - 30 years) predominantly male [7]. Data for this study was consistent to those of the literature with an average age of 23.7 years. The similar result has been found by other authors with a mean age of respectively 23, 9 and 24 [2] [10].

The orbital complications in this study have been reported in a child of 6 years old. According to the literature, these complications are found in both children and adults [11] [12].

The use of non steroidal anti-inflammatory drugs (NSAIDs) before health facilities was found in 4 cases. These molecules have been evoked as risk factors, this by increasing the production of caliciform cells and leucotrienes whose are responsible of the secretory metaplasia of the sinus mucosa. This phenomenon will contribute to the suppuration of sinusitis, especially if an appropriate antibiotic therapy is instituted [2] [13].

The human immunodeficiency virus HIV is also involved in the emergence of dangerous sinusitis [2]. Few studies have shown the involvement of HIV in the occurrence of complications [14]. One case of frontal sinus abscess associated with HIV was encountered in a woman 31 years old.

The average of care seeking duration was 12.9 days longer than 5.50 and 6.47 days of other authors. This long time can be due to the use of non-steroidal anti-inflammatory drugs which can reduce pain postpone the diagnosis and management by a specialist since the first symptoms of sinusitis complication.

The diagnosis of sinusitis complicated has been performed based on clinical and radiological signs. Frontal sinusitis complication was the most seen but the pansinusitis, as reported in this study [1] [5]. The fever has been constantly found in our series and was related to the biological signs of the inflammation. However, it has been found in $56.3 \%$ of cases in the series of Otmani [10].

The frontal subperiosteal abscess manifesting by a soft frontal tumefaction, fluctuating and painful was encountered in frontal sinusitis. The similar observation was made by some authors. They are the consequence of the spread of sinus infection of the anterior frontal sinus wall [1] [8].

Table 1. Summary of 9 patients with sinusitis complications.

\begin{tabular}{|c|c|c|c|c|c|}
\hline patients & $\begin{array}{c}\text { Patient 1/M/6 } \\
\text { years }\end{array}$ & $\begin{array}{c}\text { Patient } \\
\text { 2/F/16 years }\end{array}$ & $\begin{array}{c}\text { Patient } \\
\text { 3/M/12 years }\end{array}$ & $\begin{array}{c}\text { Patient } \\
\text { 4/M/14 years }\end{array}$ & $\begin{array}{c}\text { Patient } \\
\text { 5/M/19 years }\end{array}$ \\
\hline $\begin{array}{c}\text { Sinus } \\
\text { involved }\end{array}$ & $\mathrm{E}$ & $\mathrm{P}$ & $\mathrm{P}$ & $\mathrm{F}$ & $\mathrm{E}$ \\
\hline complications & $\begin{array}{c}\text { Orbit } \\
\text { subperiosteal } \\
\text { abscess }\end{array}$ & $\begin{array}{l}\text { Fever, headaches, } \\
\text { consciousness } \\
\text { disorders }\end{array}$ & $\begin{array}{c}\text { Fever, O, R, } \\
\text { headaches, } \\
\text { consciousness disorders }\end{array}$ & $\begin{array}{l}\text { Fever, } \mathrm{R}, \mathrm{O}, \\
\text { frontal fluctuating } \\
\text { tumefation }\end{array}$ & $\begin{array}{c}\text { Fever, palpebral } \\
\text { oedema } \\
\text { thrombosis }\end{array}$ \\
\hline
\end{tabular}

E: ethmoidal, F: frontal, P: pansinusitis (maxillary, ethmoidal, and frontal sinus attack), $\mathrm{R}=$ rhinorrhea, $\mathrm{O}=$ nasal obstruction, ICH syndrome (intracranial hypertension), $\mathrm{M}=$ male, $\mathrm{F}=$ female.

Table 2. Summary of 9 patients with sinusitis complications.

\begin{tabular}{cccc}
\hline patients & $\begin{array}{c}\text { Patient } \\
\text { 6/M/18 years }\end{array}$ & $\begin{array}{c}\text { Patient } \\
\text { 7/M/27 years }\end{array}$ & $\begin{array}{c}\text { Patient } \\
\text { 8/F/31 years }\end{array}$ \\
\hline Sinus involved & $\mathrm{P}$ & $\mathrm{F}$ & $\mathrm{F}$ \\
complications & Brain abscess & $\begin{array}{c}\text { Fever, frontal fluctuating } \\
\text { tumefation }\end{array}$ & $\begin{array}{c}\text { Frontal subperiosteal } \\
\text { abscess }\end{array}$ \\
Frontal subperiosteal \\
abscess
\end{tabular}


The subperiosteal abscess of the orbit was revealed by eye-orbital symptoms including unilateral axial exophthalmia with decreased visual acuity in 1 case. It was due to the spread of infection in the ethmoidal orbit [15]. The cavernous sinus thrombosis was revealed by a right ptosis, external oculomotor nerve paralysis, it was associated with meningeal syndrome as reported by Amat F. [4]. Other orbital complications of ethmoidal infection such as preseptal cellulitis, intra orbital abscess have been reported [2] [4] [10].

The symptoms of endocranial complications are highly variable. It may be a persistent acute headache, a meningeal syndrome, a motor deficit, convulsive crisis, altered consciousness or an intracranial hypertension syndrome [7]. In this study these symptoms have been revealed by headaches, consciousness disorders, meningeal syndrome, motor deficit and intracranial hypertension syndrome (ICHS).

The computer tomography has been requested in all patients and helped to confirm the diagnosis and to localize the sinus attack. The front seat was in $44.4 \%$ of cases, pan sinusal in $33.3 \%$ and ethmoidal in $22.2 \%$ of cases. In Otmani N. et al. [10] the causal sinusitis was ethmoid in $50 \%$ of cases, front in $25 \%$ of cases, maxillary $6.25 \%$ and pansinusal in $18.75 \%$ of cases.

The endocranial complications reported in this study were due to a pansinusitis. The same observation has been made by several authors [6] [7]. However for other authors, they were due to frontal sinusitis [2] [9].

The maxillary locations, the most common in practice are less associated to the risk of complications [16]. These data support the results of our series. Nevertheless orbital complication cases of maxillary sinusitis have been reported [3].

Certain factors influence the result of the samples microbiological analysis. It is amongst other the rigor of the samples collection techniques, transportation and processing delay, the previous anti-infectious treatments received by patients [6] [17].

The samples have been collected in per surgery and immediately sent to laboratory. The result remains sterile in 4 cases and this can be explained by antibiotherapy before bacteriological sample collection.

Germs found in the literature are aerobic and or anaerobic. Sometimes the infection is polymicrobial, mixed, combining aerobic and anaerobic bacteria Streptococcus pneumonia (3 cases), Pseudomonas aerugenosas (1 case) and Staphylococcus aureus (1 case) [6] [7] [11]. Similar bacteria have been found by other authors [2] [18].

The treatment of complicated sinusitis is a medical and surgical emergency [5]-[7].

The choice of empirical antibiotic therapy will be made based on the susceptibility of the germ, based on epidemiological data, the proper antibiotic diffusion, the field, the starting point [5].

The rule of antibiotic therapy is an association of 2 or 3 antibiotics [2] [5].

For endocranial complications, some authors recommend a triple antibiotic therapy based on third generation of cephalosporin associated to vancomycin and metronidazole [5]. Other authors have preferred the association of cephalosporin 3rd generation and metronidazole [7].

For orbital complications a dual antibiotic therapy is usually recognized which associates a 3rd generation cephalosporin and an anti staphylococci. An imidazole can be associated in case of suspicion of an infection by anaerobic [19].

In this study the endocranial complication cases and two frontal abscess cases have had a dual antibiotic therapy associating cefotaxime and metronidazole and the other cases have had an association of amoxicillin-clavulanic acid.

The duration of the antibiotic therapy has not been the object of consensus in the literature. According to Belcaid A. [2] intravenous antibiotic therapy should be maintained until an apyrexia is obtained, and after disappearance of local inflammation signs. The oral route takes over for 2 to 8 weeks with an average of 3 weeks. In our series the average time was 28 days with extremes of 8 and 45 days.

Surgical treatment includes drainage of complications and drainage of sinusal site [2] [3] [7].

The surgical approach depends on the affected sinus and complications site [2] [5].

The external approach has been used in this study for frontal and pre septal abscess. Some authors have recognized mixed, external and endoscopic approach which gives a better result and will enable easily later achieve a surgery filling of frontal sinus [2] [14]. Internal approach is not feasible yet in our context because of the non availability of endoscopy equipment. In our series, two cases of subdural empyema have necessitated neurosurgical care. The terms of the treatment of neurosurgical complications are variable according to the authors [2] [17]. For voluminous intracranial collections that obstruct the cerebrospinal fluid pathways, neurosurgical drainage is indicated in emergency [20]. Small collections $\leq 1 \mathrm{~cm}$ without focal signs or intracranial hypertension 
syndrome are treated with antibiotic therapy for 6 weeks associated to an endoscopic drainage of the sinusitis [21].

The endocranial complications of sinusitis can be life-threatening. They can cause neurological injuries [1] [7]. We had neurological sequelae and two patients died. However Page C. et al. [7] have reported severe neurological sequelae in 3 patients in a series of 22 cases of intracranial abscesses and empyema. Two cases of hemiplegia as and frontal syndrome and one case of aphasia and behavioral disorders have been reported.

Orbital complications can be responsible for visual sequelae, the most serious of which is the definitive blindness [3]. We did not notice any sight injury as the case of definitive blindness reported by Guibert M. et al. [3].

\section{Conclusion}

Complications of infectious sinusitis are extremely serious despite the brain abscess and much difficult to tackle because of antibiotic era. The computer tomography was imperative to perform the diagnosis. The prognosis should be much better by specific antibiotics at the right time.

\section{References}

[1] Gilain, L. and Manipoud, P. (1995) Cranial and Intracranial Complications of Sinonasal Infections. EMC ENT (Ear, Nose, Throat), 20-445-A-10, 17 p.

[2] Belcaid, A. (2011) Complications of Sinusitis (about 80 Cases). Thesis, Sidi Mohammed Ben Abdellah University Faculty of Medicine and Pharmacy Fes/Moroco, No. 143.

[3] Guibert, M., Avenard, M., Rose, X., Cabos, A., Pessey, J.J. and Sorrano, E. (2008) Major Orbital Complications of Acute Maxillary Sinusitis of Dental Origin. Journal of Rhinology Laryngology, 129, 319-323.

[4] Amat, F. (2010) Complications of Bacterial Sinusitis in Older Children about a Case and Review of the Literature. Archives of Pediatrics, 17, 258-262. http://dx.doi.org/10.1016/j.arcped.2009.11.012

[5] Hammami, B., Masmoudi, M., Charfeddine, I., Mnejja, M. and Ghorbel, A. (2014) Support for Orbital and Intracranial Complications of Acute Bacterial Sinusitis. Journal Tunisien d' ORL, 31, 5 p.

[6] Moussala, M., Meli, J., Bengono, G., Binam, F. and Ekeke Monono, M. (1998) Oculo-Orbital Complications of Acute Sinusitis in Ophthalmic Consultation in Cameroon, Epidemiological Aspects and Associated Mortalities. Black Africa Medicine, 45, 111-114.

[7] Page, C., Lehmann, P., Jeanjean, P., Strunski, V. and Legars, D. (2005) Intracranial Abscess and Empyema ENT Origin. Otolaryngology Head and Neck Surgery Annals, 122, 120-126.

[8] Jaswal, A., Jana, A.K., Sikder, B., Jana, U. and Nandi, T.K. (2007) Frontal Sinus Osteomyelitis with Midline Fistula. Indian Journal of Otolaryngology and Head \& Neck Surgery, 59, 284-257. http://dx.doi.org/10.1007/s12070-007-0082-6

[9] Jones, N.S., Walker, J.L., Bassi, S. and Jones, T. (2002) The Intracranial Complications of Rhinosinusitis: Can They Be Prevented. Laryngoscope, 112, 59-63. http://dx.doi.org/10.1097/00005537-200201000-00011

[10] Otmani, N. (2010) The Orbital Complications of Sinusitis (about 16 Cases). Thesis, Sidi Mohammed Ben Abdellah University Faculty of Medicine and Pharmacy of Fes/Moroco, No. 059.

[11] Barry, B., Ameline, E., Thuong, M., Brunel, F., Pichelin, C. and Géhanno, P. (2000) Orbital Complications of Sinusitis in Adults. Otolaryngology Head and Neck Surgery Annals, 117, 19-25.

[12] David, J. and Stearns, M.P. (1994) Orbitol Complications of Sinusitis: Avoid Delays in Diagnosis. Journal of Postgraduate Medicine, 70, 108-110. http://dx.doi.org/10.1136/pgmj.70.820.108

[13] Ognibene, R.Z., Voegels, R.L., Bensadon, R.L. and Butugan, O. (1994) Complications of Sinusitis. American Journal of Rhinology, 8, 175-179. http://dx.doi.org/10.2500/105065894781874331

[14] Mortimore, S. and Wormaid, P.J. (1999) Management of Acute Complicated Sinusitis: A 5-Year Review. Otolaryngology—Head \& Neck Surgery, 121, 639-642. http://dx.doi.org/10.1016/S0194-5998(99)70072-0

[15] François, M. (2008) Ethmoidites Acute in Children. EMC ENT, 20-440-A-1, 7 p.

[16] Gilain, L. and Laurant, S. (2005) Maxillary Sinusitis. EMC ENT, 17-485-A-10, 7 p.

[17] Marfatia, H., Saha, A. and Kirtane, M. (2001) Complication of Frontal Sinusitis-Not Amenable to Endoscopic Surgery. Indian Journal of Otolaryngology and Head and Neck Surgery, 53, 183-185.

[18] Boko, E., Lescane, E., David, M., Kpémissi, E. and Beutter, P. (2004) Bacteriology of Chronic Maxillary Sinusitis and Sensitivity to Common Antibiotics. Descriptive and Evaluative Study about 78 Samples Taken at the University Hos- 
pital of Lomé in Togo. The Letter of Oto-Rhino-Laryngology and Neck Surgery, 294, 14-16.

[19] Miloundja, J., Ategbo, S., Mandji Lawson, J.M., Mouba, J.F., Lessaka, P., Nziengui, A., Nzenze, S. and N’zouba, L. (2011) Acute Externalized Ethmoidites Child about 9 Cases. Black African Medicine, 58, 150-155.

[20] Ley, D. (2001) Intracranial Abscess and Empyema. EMC Neurology, 17, 7 p.

[21] Nlend, A., Wamba, G., Same Ekobo, C. and Morisseau-Leroye, J. (1996) Medical a Subdural Empyema by Phenicol Monotherapy Treatment. Black African Medicine, 43, 310-311. 